\title{
Federal Services to Libraries: Progress Report on the Survey
}

Mr. Temple is librarian, Georgetown University.

$\mathrm{T}$ HERE IS NOTHING more attractive than an invitation to accomplish the impossible. Therefore when John H. Ottemiller, associate librarian of Yale University and Chairman of the ALA Federal Relations Committee, suggested to the writer that he obtain a leave of absence for eight weeks and in that time make a survey of Federal services to libraries and the policies governing them and present this information in the form of a written report, the only possible answer was "Yes." Since this was such an unusual assignment, it has been suggested that the methodology used in organizing and carrying out the project would be of interest to librarians generally.

The assignment grew out of a directive addressed to the Federal Relations Committee by the ALA Executive Board, calling for a comprehensive review of the relationships between the government and libraries. The purpose of such a review was to provide a factual basis to guide ALA in its dealings with the Federal establishment. A subcommittee of the Federal Relations Committee met in Washington in the spring of 1953 and decided that a study should be undertaken immediately to achieve these objectives:

I. Review the literature growing out of previous studies and surveys of Federal services of benefit to libraries.

2. Provide a statement of the policies governing such services.

3. Compile a descriptive list of services currently rendered from Washington by the Federal government to nonfederal libraries within the continental United States.

The severity of the time limitation, even after the eight weeks originally allotted had been extended to ten, posed a difficult problem. It is the purpose of these remarks to define that problem and to describe the methods used to solve it.

In the first place it was discovered that nobody could say just how many Federal agencies there are in Washington because of the difficulty in defining "agency." The proposed survey was to cover not only the services given by Federal libraries, but by Federal agencies of whatever kind. A count made in 1952 had indicated 133 Federal libraries in the Washington area. The Britannica Book of the Year, 1952 lists some I5o-odd agencies; the Civil Service Commission officially lists io executive agencies and 49 independent agencies, making a total of 59; the Bureau of the Budget does the same; while the United States Senate Committee on Government Operations has issued a large chart ( $3 \frac{1}{2}$ feet by 3 feet) entitled Organization of Federal Executive Departments and Agencies which proved, in the light of the ten week limitation, a thoroughly discouraging document inasmuch as it lists in small print every imaginable department, bureau, office, authority, division, administration and board.

Obviously a number of agencies given official listing in the Federal Register would be irrelevant to the purposes of the survey, and could be eliminated at once: the War Claims Commission, for example. On the 
other hand, one of the most productive agencies in the government, service-wise, is the Department of State, and this Department's multifarious offices are spread out in 27 different buildings all over the city. While it is true that wholesale elimination of apparently irrelevant agencies might well deprive the survey of valuable but hidden services, the number of first choice agencies was so large that no practical problem was faced in the actual event, except that of covering as many of these as possible in as short a time as possible.

It was at this point that ordinary interview techniques proved completely inadequate. Supposing that the task were merely to interview all of the key personnel in the Library of Congress alone, it would still be impossible in ten weeks to gather, write up, verify, organize and produce in typewritten form all of their data. And the Library of Congress was only one-albeit a most important one-of the many agencies to be covered. Accordingly the following procedures were followed:

A mimeographed statement was drawn up defining briefly the objectives of the project, and stating explicitly the kind of cooperation wanted from each individual interviewed. It must be emphasized that this statement was not a questionnaire, but an interview sheet, sent in advance of each interview so that the person with whom the discussion was to take place would have a grasp of the principal purposes of the interview before it took place. One of the most common reactions at the outset of the interview itself was a puzzled and unhappy declaration by the Federal official that after all, everybody already knew what he and his organization were doing to help libraries, and what could he say that would be of value?

To meet this situation an exhaustive list of catch-headings was attached to the interview sheets. These headings covered prac- tically every conceivable category under which, a service might be classified, and made it abundantly clear that the survey was not confining the word "service" to its customarily narrow precincts, but on the contrary conceived it to mean any contribution or assistance by the government to the conduct and welfare of nonfederal libraries. 'Then, as the Federal official would glance down the list and begin commenting on or asking questions about one entry or another, a solid core of service data would begin to emerge-nearly always to the surprise of the official himself. In this manner were drawn forth both obvious and hidden services; services direct and indirect; consultative and advisory services as well as operating programs; cooperative projects involving the joint activity of Federal and nonfederal libraries; services which are byproducts as well as primary objectives; legislative measures subsidising library operations; services asked for but refused, or offered but no longer needed-and running the gamut from abstracting services, card distribution, declassification projects and exchanges to photoduplication, reference assistance, subject headings projects, translation services and union catalogs."

However, the very thoroughness of the interviews, which lasted from ten minutes to an hour or more, presented a further difficulty. How was all this information to be garnered in accurate form and verified? Obviously not at the interview itself, or the interviews would be extended to a half day each. The solution lay in adopting a technique of self-enumeration which guaranteed three factors vital to the success of the project: speed, accuracy, and a division of labor. It was through the use of $5 \times 8$ inch cards that this was accomplished. As the interview progressed and the official would start talking about some service or contribution to libraries, the interviewer would jot down at the top of a blank card 
an appropriate subject heading. When a new point was introduced, the same would be done on another card. At the end of the interview-when both the official and the surveyor had already forgotten much of the wording and details of what had been said-the official would be presented with the pack of subject-headed cards and the request that, with these as reminders, he prepare or have prepared a concise typewritten statement on each topic, using a separate card for each topic, and to send the completed cards to the interviewer at the ALA Washington Office (whose facilities had been cordially placed at the surveyor's disposal). In this fashion it was possible to set successive series of people to work on the compilation phase while the surveyor went on to other agencies to repeat the process.

While this procedure produced a success that was qualitatively satisfactory and sometimes quantitatively embarrassing, a major obstacle still remained. This was, briefly, the problem of how to hold hundreds of interviews within the six weeks allowed for the fact-gathering phase without achieving the miracle of bilocation. This problem was happily reduced to manageable proportions because of the cooperation of the administrations of the three largest institutions to be covered: the Armed Forces Medical Library, the Department of Agriculture Library, and the Library of Congress. In the case of the first two, arrangements were made for the surveyor to appear at a department head meeting, to present his case, distribute copies of the project statement, and then leave the task of assembling the requisite information on $5 \times 8$ inch cards to the various department heads and their staffs. A date was set by which the information would be ready, and the surveyor then used the time thus gained to contact other agencies.

At the Library of Congress a similar but more elaborate pattern was developed. The
Librarian designated an administrative assistant who was to be the surveyor's point of contact there. After a long interview with this individual, who grasped the situation at once and made many valuable suggestions, a special statement was drawn up for the five top administrators at the $\mathrm{Li}$ brary of Congress, and these administrators received a careful briefing on the purposes and details of the project. The five administrators then instructed their department heads. They, in turn, picked from their staffs the appropriate individuals to assemble the information on cards. The completed cards were then channelled back through the same chain of command to the administrative assistant who originated the process, and who was responsible for scanning and clearing the cards before turning them over to the surveyor. When a card was found to be incomplete or unclear, it was returned for clarification to the staff member who wrote it, with appropriate inquiries. It was in anticipation of this contingency that the instructions to cooperators included the signing of the name and title of the individual writing the card.

If there is one fact that stands out above all others among the findings of the survey, it is the fact that no one individual in existence has an adequate idea of the number, extent, variety and nature of the services actually being given or potentially available to the librarians of this country by their government. Mountainous as the data seemed when they had all been collected, there is no pretension that they constitute a complete picture of Federal services. This was forcibly brought out when, during at least half of the interviews, suggestions were received as to other agencies or offices which had something to contribute to the service pattern. Many of these suggestions were followed through and proved productive, but in the end no way was found to slay

(Continued on page 235) 
Wilson made several unique contributions to the field of publishing. One of the most notable is the plan he originated for saving and interfiling type for the "cumulative" indexes associated with his name.

Another unusual contribution is the "service basis" method of charge, which not only made possible the publications of hundreds of reference volumes, but made it financially possible for libraries on six continents to own them.

Mr. Wilson served as president of the publishing firm bearing his name from its beginning until December 1952, when he requested that he be relieved of some of his administrative duties in order to devote more time to a study of the company's general policies and future plans. He was accordingly named Chairman of the Board of Directors and was succeeded as president by Howard Haycraft, who had been vice-president since 1940 .

As the man who was regarded by many as the greatest benefactor of libraries since Andrew Carnegie, Mr. Wilson received numerous honors from educators and librarians.
Brown University conferred on him the honorary degree of Doctor of Letters in 1939, and in 1948 he received from the University of Minnesota its first "Outstanding Achievement" medal. Both the American Library Association and the Special Libraries Association paid special honor to him in 1948 , on the fiftieth anniversary of his firm's first publication, and in 1950 he received the American Library Association's \$500 Joseph W. Lippincott Award for Outstanding Achievement in Librarianship. In the same year the University of Minnesota Press published an account of his achievements, John Lawler's The H.W. Wilson Company: Half a Century of Bibliographic Publishing, with a foreword by E. W. McDiarmid, a past president of the American Library Association, in which he said, "Wilson has played a vital ... part in nearly every scholarly activity of the past half-century."

A tribute is paid to Mr. Wilson by C. Sumner Spalding in the January 1954 issue of $C$ E $R L$ for his interest and work in relation to the Library of Congress printed catalogs.

\section{Federal Services to Libraries}

\section{(Continued from page 178 )}

the dragon of arithmetical progression.

The results of the survey are being published in book form late this spring by the American Library Association under the title of Federal Services to Libraries. Part I is to be devoted to an exposition of the policies governing Federal services to libraries, and Part II (the main section of the book) will consist of an alphabetical listing by subject of the services available to libraries from the government at the time the typescript went to press early in 1954. Each service is described in sufficient detail to make it meaningful. Finally there is an index in which every service, book, document, individual or agency mentioned in the text is cited by page reference, and under the name of each agency are to be found the services it offers.

Since nothing changes more rapidly than the Federal scene in Washington, it is only fair to the Federal personnel who cooperated in this work to mention that some of the services listed may have been modified or discontinued in the interim between reportage and publication, and that all Federal services to libraries or to any other organizations or individuals are dependent upon such variables as budget and staff. Conversely, some services may well have been inaugurated after the book went to press. Nothing less than a looseleaf service could hope to achieve current coverage of this field. It is nevertheless the hope and belief of the Federal Relations Committee that librarians and others will find in Federal Services to Libraries a key to many services offered by their government but hitherto not used by many libraries which stand to benefit from them. 